\title{
The transformation of the communication infrastructure in relation to spatial and landscape changes of cities based on the example of Wroclaw
}

\author{
Anna Katarzyna Andrzejewska ${ }^{1, *}$ \\ ${ }^{1}$ EngD, Department of Urban Planning and Settlement Processes, Faculty of Architecture, Wroclaw \\ University of Science and Technology, ul. B. Prusa 53/55, 50-317 Wroclaw, Poland
}

\begin{abstract}
Infrastructural transformations are an indispensable element of developing cities. They condition the proper flow of goods, information and people. The communication infrastructure is of particular importance for cities, which determines their proper functioning. Difficulties in accessing space are often one of the main barriers blocking the intended development direction. On the other hand, in order to prevent the currently occurring phenomenon of city sprawl, it is necessary to focus new investments within already existing transport corridors located closer to the center. Such an approach has the chance of implementing an alternative to the progressing phenomenon of suburbanization in the form of promoting the concept of the so-called compact city. Thanks to such activities, the urban potential has a chance to be maximized. As part of this article, based on the example of Wroclaw, the transformation of road infrastructure has been tracked in relation to the ongoing spatial and landscape changes. An interpretation of the recurrently modified study of conditions and directions of spatial development of Wroclaw, showed the relationships that occur between road infrastructure and urban space and the surrounding landscape.
\end{abstract}

\section{Introduction}

The level of infrastructural management of cities, as well as taking into account the reserves of the future infrastructure potential, testify to the economic development of the region. Furthermore, the level of infrastructure development which is in the area within a specified time, affect the attractiveness of a given place. This is closely related to the infrastructure performing one of the basic functions of satisfying the demand for services. Therefore, the serving of the consumption zone is essential.

Individual networks, devices and objects of technical infrastructure are primarily characterized by the principle of complementarity with each other, which means that they are interrelated and their functioning is often dependent on each other. Another of their attribute is their relative longevity, but also the expense of implementation mainly due to

${ }^{*}$ Corresponding author: anna.andrzejewska@pwr.edu.pl 
the fact that they often require comprehensive realization, and this entails substantial costs on time. Infrastructure investment planning has a definitely long-term character which in turn requires careful planning and which needs to be updated on a regular basis.

The technical infrastructure supports spatial and economic units of a various scope starting from the area of a particular investment further through the area of the estate or the district and throughout the city, municipality or country. They provide specific services in the field of energy, heating, gas, telecommunications or water supply, or the removal of wastewater and waste. However, it is undeniably a locational function that is associated with transport that in a special way binds all other infrastructural elements. Infrastructure, which is connected with communication, acts as a kind of bloodstream [1]. The efficiency of traffic flows determines the convenient availability and proper functioning of cities. According to Deyan Sudjic, the control of a city is via individual streets, which are subject to changes as its growth [2] and in fact it really is.

Transformations of road infrastructure are an interesting phenomenon in cities, because they cause a whole range of spatial and landscape changes. Tracing the changes to the document of the study of conditions and directions of spatial development of Wroclaw will show the validity of the above statement.

\section{A document of a study of the conditions and directions of spatial development in Wroclaw}

According to art. 9 par. 1 of the Act of 27 March 2003 on spatial planning and development, the study of conditions and directions of spatial development determines the spatial policy of the community and the local rules for the development of individual territories [3]. This document is to coordinate the arrangements of local spatial development plans. However, it is not an act of local law, but it plays an important role in the planning system as a general planning act [4].

The history of creating a study on the conditions and directions of spatial development of Wroclaw can be divided into three basic stages. The original model of the Study was a study from 1998 [5], which was based on the then 1994 spatial development law [6]. This act was the beginning of the spatial planning system in Poland. However, it required a comprehensive complement and refinement of its individual elements to create a cohesive, well-functioning whole as possible. In 2003, therefore, another law on spatial planning and development was adopted [3] and based on its assumptions in 2006 Wroclaw received a second study [7]. Four years later heated discussions on planning law in Poland led to the amendment of the 2003 Act. Wroclaw did not remain indifferent to the proposed changes in the amended act, the more so that they were largely related to the study document, therefore in 2010 a change of the study of conditions and directions of spatial development of Wroclaw was approved [8]. The third, currently valid document of the study for the City of Wroclaw was adopted at the beginning of 2018 [9]. And just as the two previous versions were largely due to the changing planning law in the meantime, the latter was the result of the many reflections and needs of ideological and perspective changes for the city while taking into account social needs as a result of participatory activities.

\subsection{Analysis of the Study from 1998}

The first study of the conditions and directions of spatial development of the Wroclaw community was adopted by Resolution No. XLVIII/680/98 of the City Council of Wroclaw of January 30, 1998. This document was prepared in cooperation with the Wroclaw 
Development Office with the Wroclaw University of Technology. It was the first attempt at a comprehensive approach to the existing and planned functional and spatial structure of the city, including a comprehensive infrastructure, spatial and landscape layouts. The following illustration of the study clearly shows the hierarchy of individual areas: urban complexes and open landscape areas included in the grid of existing and planned infrastructural elements (Fig. 1).

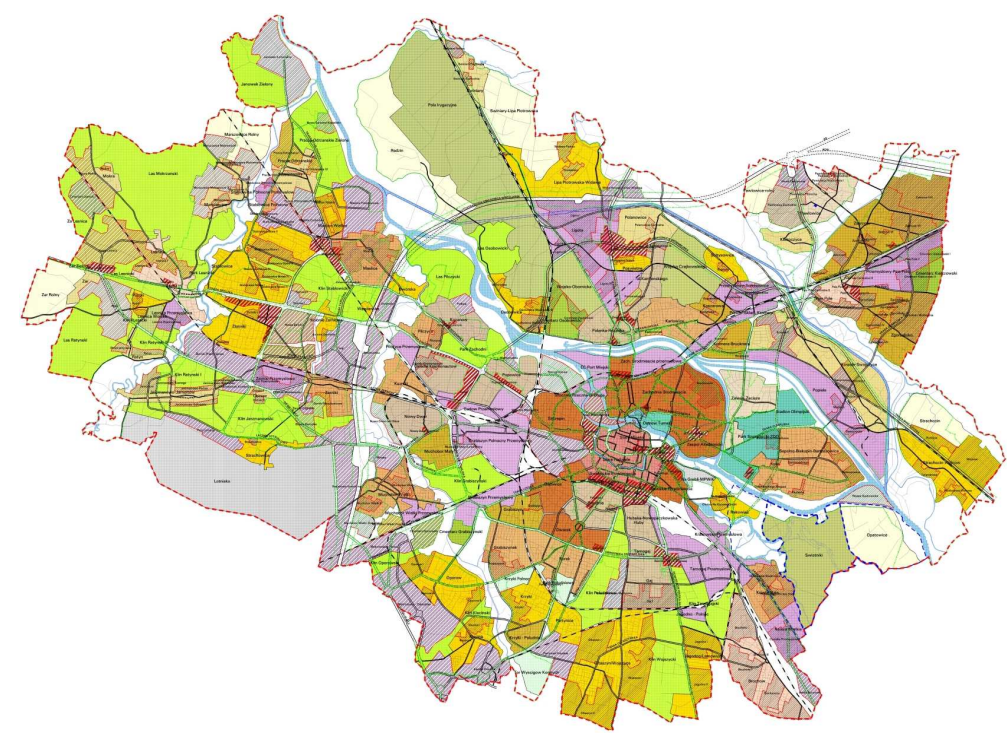

Fig. 1. Functional and spatial structure of the city [10].

The basic elements of the Wroclaw transport system according to the Study document of 1998 were: roads, bicycles, railways, airports and river beds (Fig.2).

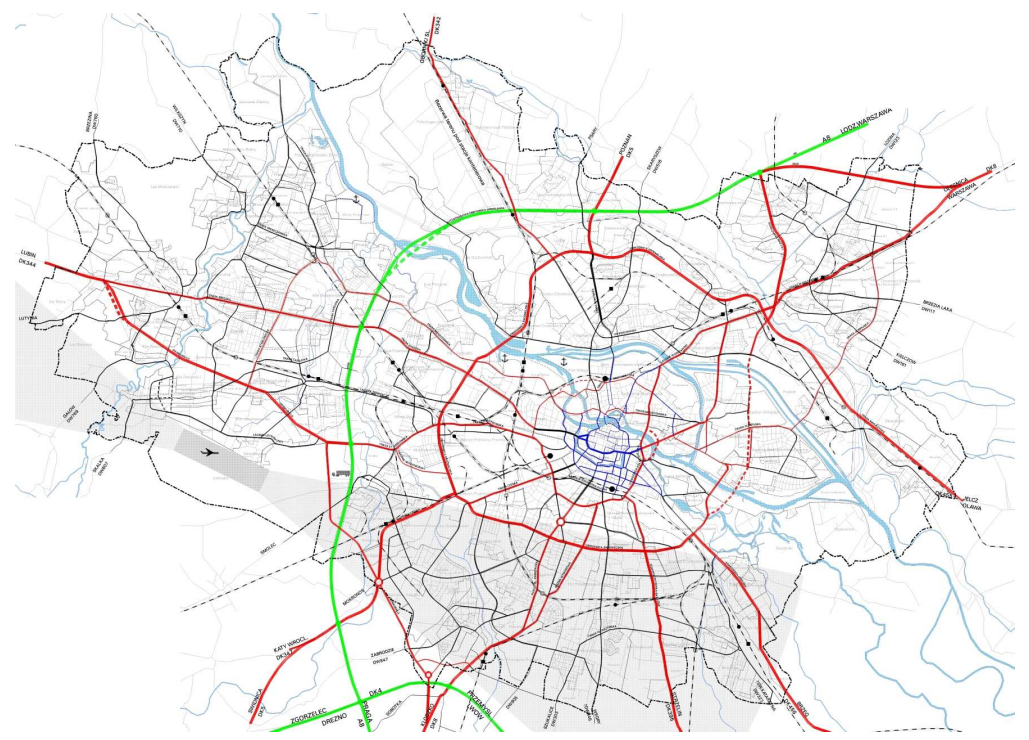

Fig. 2. The basic elements of the transport system [10].

Among the road infrastructure, the following were specified: highways - A8 towards Prague-Łódź/Warsaw and DK4 towards Zgorzelec-Przemyśl/Lviv, the most important GP 
class roads - main accelerated traffic, G class - main and Z-class - collective. The hierarchy of roads is marked with the thicknesses of individual lines, the state existing with solid lines and the variants of the routes with dashed lines.

The initial study of Wroclaw strongly demanded decisive actions aimed at the development of a communication system based on significant routes of bypasses, switches and axes (AOW - "Wroclaw Motorway Bypass", "Downtown Ring Road", "Pawłowice Link" or "Incubation Axis"). The need to modernize and extend the street system for innercity and transit traffic was signaled.

\subsection{Analysis of the Study from 2006 with the amendment of 2010}

The next version of the Study of conditions and directions for spatial development of Wroclaw was adopted by Resolution No. LIV/3249/06 of the City Council of Wroclaw of July 6, 2006, as amended by the Resolution No. L/1467/10 of the City Council of Wroclaw of May 20, 2010 r. The document was prepared by the Wroclaw Development Office. Analyzing the changes that have been introduced to the second study of Wroclaw, the distinctive types of urban complexes are clearly distinguished (Fig. 3).

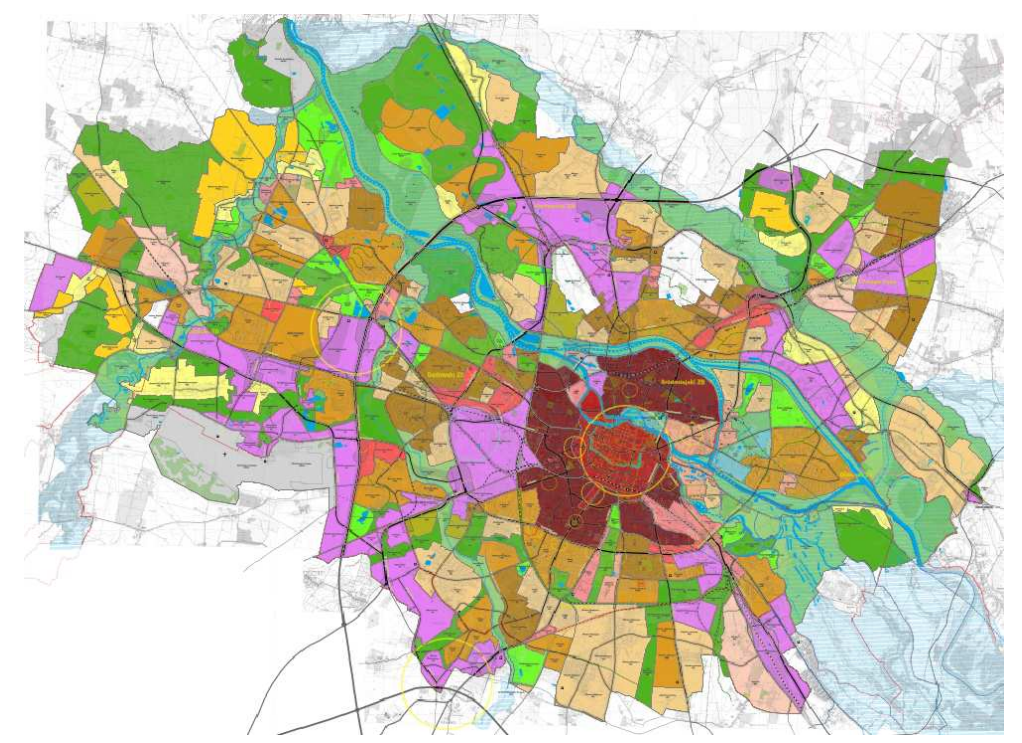

Fig. 3. Directions of spatial development - functional and spatial structure [10].

In addition, the systems of green wedges in the new version of the document already have a more reasonable continuation and the significance of river valleys from the spatial and landscape perspective is also clearly underlined.

As for changes in the approach to the communication infrastructure, in the Wroclaw study of 2010, three large motorway interchanges were clearly identified (Fig. 4). The course and importance of roads have undergone significant modifications, such as the partial elimination of the previously proposed Strzegomska Route, between Nowy Dwor and Muchobor Mały, in favor of running the Muchoborska Route, which resulted, inter alia, from the introduction of one of the motorway interchanges at the Millenium Park. 


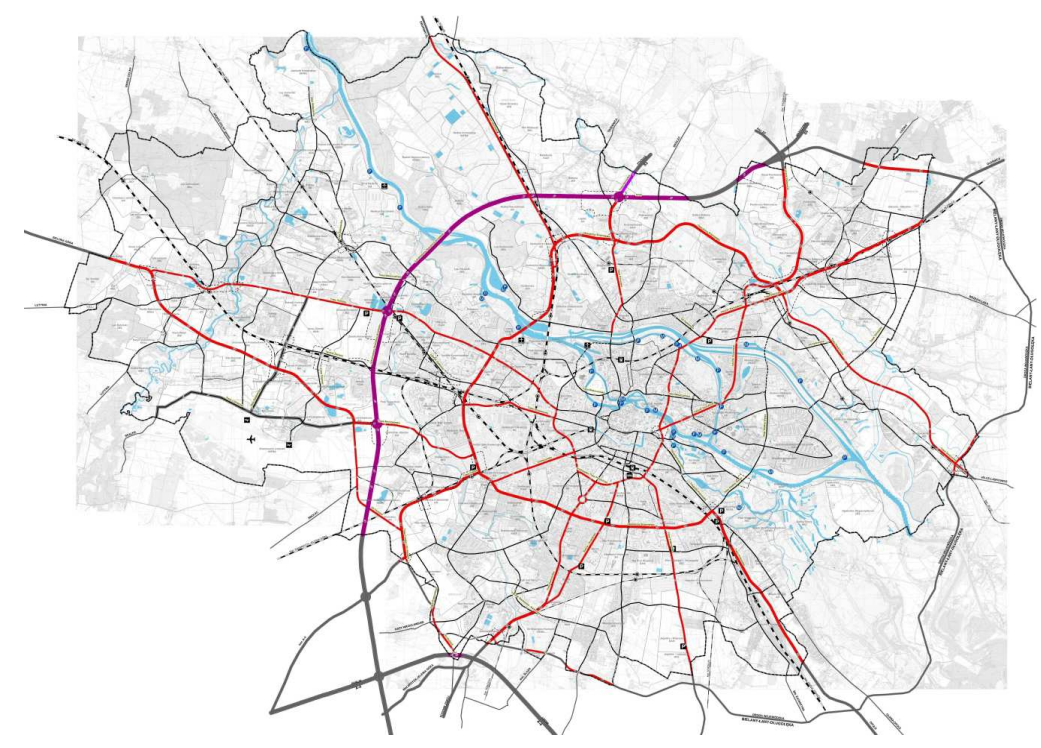

Fig. 4. Directions of spatial development - transport system [10].

However, the course of most streets within the city has been preserved from the previous study, but the classification hierarchy has been changed for some of them.

\subsection{Analysis of the Study from 2018}

The current document entitled Study of conditions and directions of spatial development in Wroclaw was adopted by the City Council of Wroclaw by resolution No. L / 1177/18 on January 11, 2018. The authors of the latest study are a team from the Wroclaw Development Office. Looking at the drawing of the spatial development directions, we can see changes that have occurred in relation to the previous version of the study (Fig. 5).

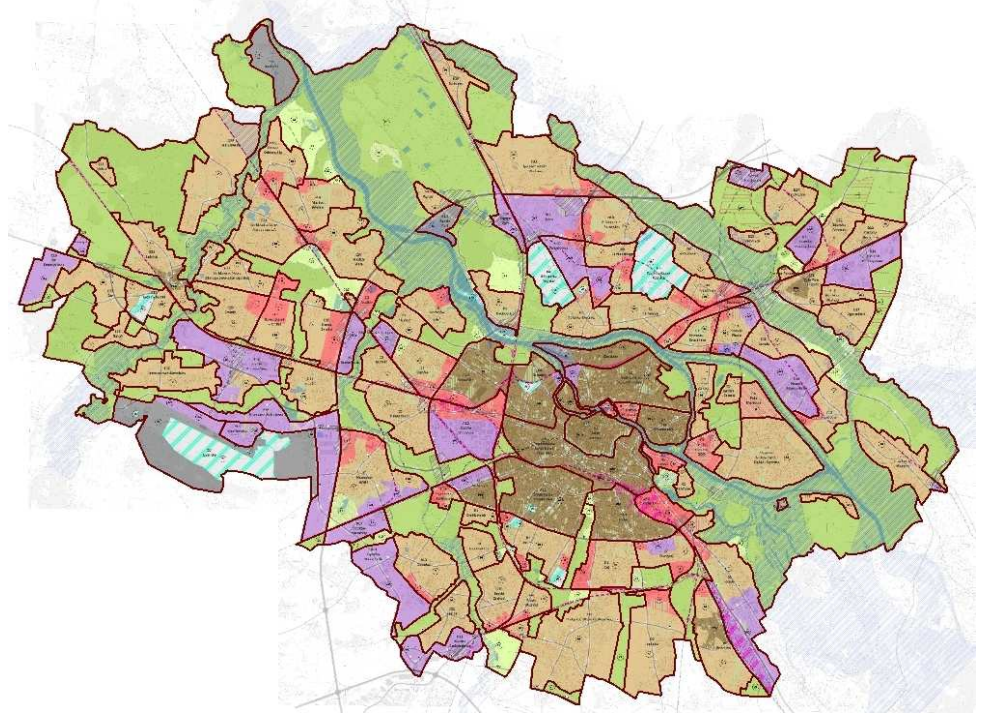

Fig. 5. Directions of spatial development - land use [10]. 
The existing band layout in the city is more clearly outlined, divided into various types of residential areas, related to business and green areas. It is postulated to maintain, strengthen and develop such land use systems in an alternating manner, while simultaneously enclosing them with an even transport system. The goal is to create a smooth system with thoughtful locations of interchange points, the proposals of which have already appeared in the study document.

In terms of changes in transport infrastructure, the new study focuses on the concept of sustainable mobility. First of all, the city was divided into zones of communication accessibility, which radiate from the center to the areas near Wroclaw (Fig. 6).

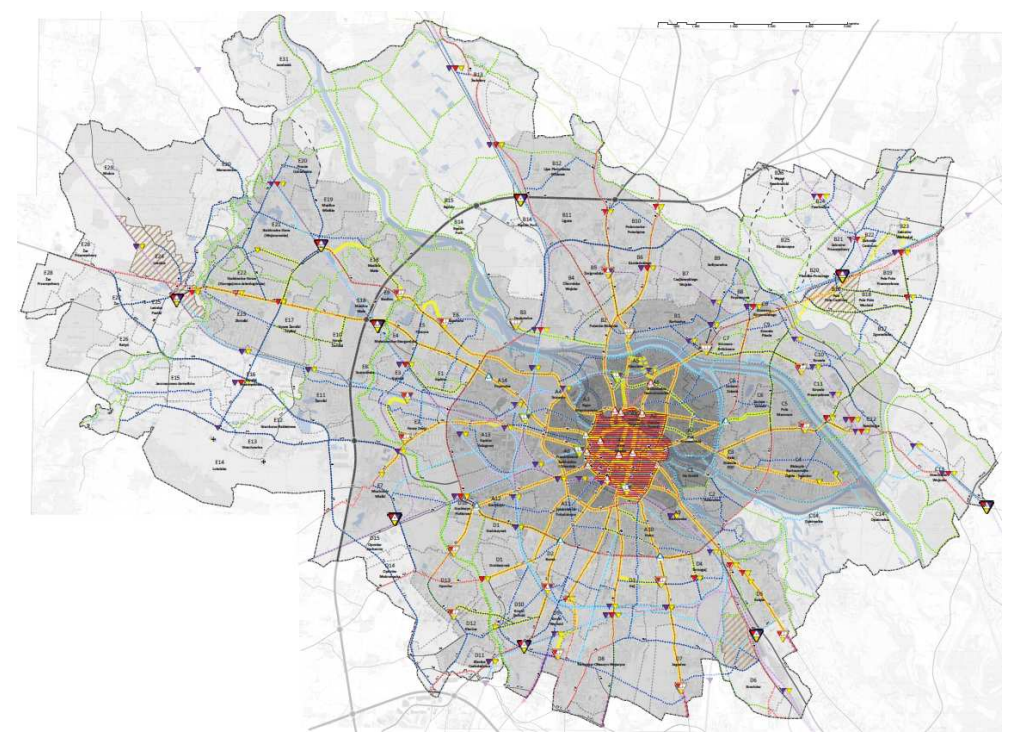

Fig. 6. Directions of spatial development - a policy of sustainable mobility [10].

Due to the growing awareness of the inconvenience caused by mass transport (air pollution, noise, lack of traffic flow) and taking into account the guidelines of the European Commission, the city has instituted the promotion of public transport. Of course, these recommendations required the development of means of urban transport with the simultaneous increase in the availability of communication networks in Wroclaw (for example, the "PLUS" tram program commuting to the Kozanów District). An important aspect of Wroclaw's new approach to urban mobility is the attempt to combine various types of collective transport in one section. Therefore, besides tram and bus transport, the railway is used, the network of which is already very densely expanded. The changes in communication were also undoubtedly influenced by new investments that were created in the city, such as the City Stadium at Królewiecka Street, which was built for Euro 2012, and many more.

\section{The transformation of the communication infrastructure and spatial and landscape changes}

Communication transformations cause spatial and landscape changes in cities. Evidence of this statement are noticeable, and felt both from the point of view of the user, as well as spatial policy. A good example of such a phenomenon in Wroclaw is the process of reconstruction of Klecińska Street, representing the main accelerated traffic (GP) class route, as part of the section of the "Downtown Ring Road". Over the years, the rank of this 
route was kept still on the same level as its course. However, the plans have changed as to how to designate its immediate environment and how to shape the meaning of streets that connect directly with it.

The following figure summarizes the comparison of how the land use of the area by three different versions of the study document created over the past 20 years. One of the clear trends in the current study is a partial return to the assumptions of the year 1998 as to the destination of the land on both sides of the ring road on the green areas on the north side of the railway line. An intermediate solution, that is the version of the study from 2010, was a proposal for the development on a wider scale already existing partly on the east side of the industrial and commercial areas (Fig. 7).
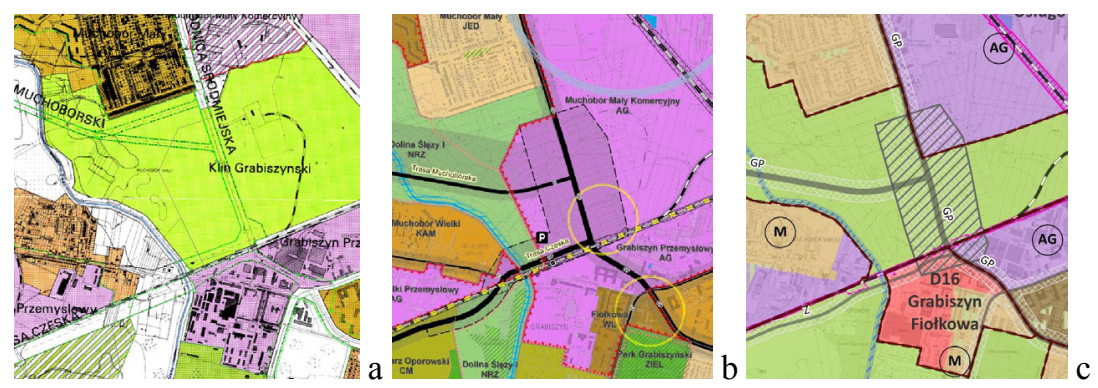

Fig. 7. The course of the fragment of the section of the "Downtown Ring Road" route according to the Study of 1998 (a), from 2010 (b) and 2018 (c) with the proposed development directions of its neighborhood [10].

In fact this diametrical change of space occurred in the year of construction of the beltway. The local residents and everyday users of this route were witnesses to the process of stage formation of the route implemented in part as above-ground runs over railway tracks (Fig. 8).
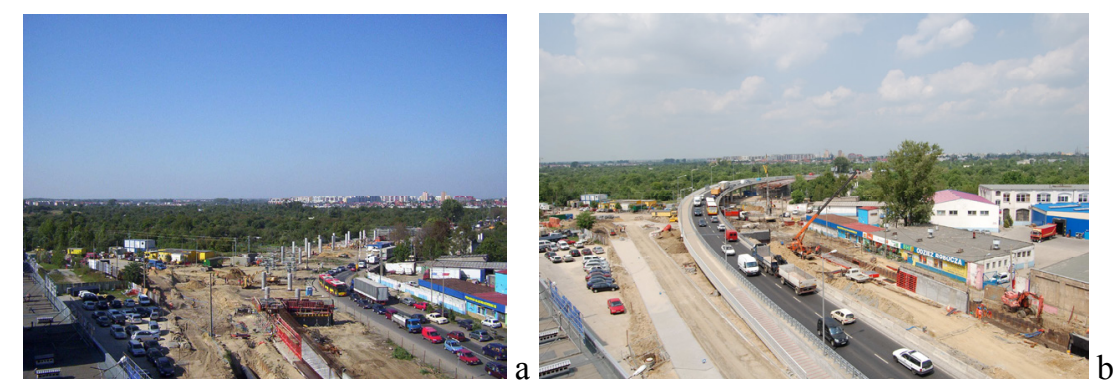

Fig. 8. The process of formation of a flyover over Klecińska Street as part of the "Downtown Ring Road" section (a - September 2006, b - May 2007), photo: author.

The construction of the flyover completely changed both visually and functionally this part of the city. Undoubtedly, it contributed to the improvement of circular communication, primarily independent of the frequency of train journeys. Road capacity has also increased through the use of two-lane roadways in both directions. A cycling and walking path was also created. The landscape of this place has also been irreversibly changed. On the one hand, the investment was definitely aggressive, due to the size of the foundation, including the significant expansion of the road bed in relation to its original dimensions. In turn, from the second point of view, the decision made to keep the green areas on both sides in the form of allotment gardens has meant that the character of the place has not been completely destroyed (Fig. 9). 

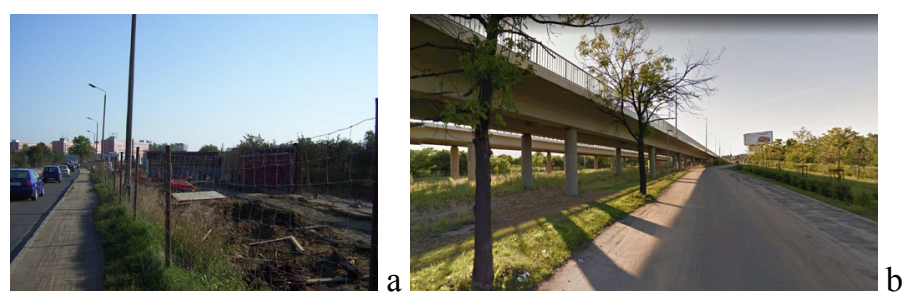

Fig. 9. Spatial and landscape changes caused by the transformation of the road infrastructure form (a August 2006, b - June 2016), photo: author.

With minimal tree felling for the new route and the introduction of additional plantings, the area of this part of the city remained as a green landscape in a slightly modified version.

\section{Summary}

Transformations in the communication infrastructure affect the conduct of the urbanization process as a result of economic development [11]. They contribute to spatial and landscape changes of cities as presented in this article. The ability to shape urban space by city authorities depends on whether such investments will not destroy the visual, but also the functional character of the place. The fact is that they will definitely change this space. However, are these changes always bad? Wroclaw is one of many examples that shows it's not necessarily.

\section{References}

1. R. Domański, Gospodarka przestrzenna, PWN, Warszawa, 90-91 (2002)

2. D. Sudjic, Język miast, Karakter, Kraków, 86-89 (2017)

3. Ustawa z dnia 27 marca 2003 r. o planowaniu i zagospodarowaniu przestrzennym, Dz. U. poz. 1073 (2017) i Dz. U. nr 80 poz. 717 (2003)

4. P. Kwaśniak, Plan miejscowy $w$ systemie zagospodarowania przestrzennego, LexisNexis, Warszawa, 51-53 (2011)

5. Uchwała nr XLVIII/680/98 Rady Miejskiej Wrocławia z dnia 30 stycznia 1998 r. wsprawie uchwalenia Studium uwarunkowań $i$ kierunków zagospodarowania przestrzennego Gminy Wroctaw

6. Ustawa z dnia 7 lipca 1994 r. o zagospodarowaniu przestrzennym, Dz. U. nr 89, poz. 415 (1994)

7. Uchwała nr LIV/3249/06 Rady Miejskiej Wrocławia z dnia 6 lipca 2006 r. $w$ sprawie uchwalenia Studium uwarunkowań $i$ kierunków zagospodarowania przestrzennego Wroctawia

8. Uchwała $\mathrm{nr}$ L/1467/10 Rady Miejskiej Wrocławia z dnia 20 maja 2010 r. $w$ sprawie uchwalenia zmiany Studium uwarunkowań $i$ kierunków zagospodarowania przestrzennego Wroctawia

9. Uchwała $\mathrm{Nr}$ L/1177/18 Rady Miejskiej Wrocławia z dnia 11 stycznia 2018 r. wsprawie uchwalenia Studium uwarunkowań $i$ kierunków zagospodarowania przestrzennego Wroctawia

10. http://gis.um.wroc.pl/imap/?gpmap=gp3 (2018.04.28)

11. A. Andrzejewska, Municipal greenery as an important element of urbanization over the centuries, PiF 27, Szczecin, 216 (2016) 